\title{
Effect of Grafting Dates on Graft-take Success and Sapling Growth of Persian Walnut (Juglans regia L.) Under Open Field Condition of Jumla, Nepal
}

\author{
Basant Chalise $^{1 *}$, Yubraj Bhusal ${ }^{2}$, Santosh Kalauni ${ }^{1}$, Raj Kumar Giri ${ }^{3}$ and Binod Prasad Luitel ${ }^{4}$ \\ ${ }^{1}$ Directorate of Agricultural Research, Khajura, Banke \\ ${ }^{2}$ Horticultural Research Station, Malepatan, Kaski \\ ${ }^{3}$ Horticultural Research Station, Rajikot, Jumla \\ ${ }^{4}$ Horticultural Research Station, Kimugaun, Dailekh
}

"Corresponding Author's Email: basantchalise@gmail.com

*Orcid ID: http://orcid.org/0000-0001-6203-1230

Received on: 13 September 2020, Revised on:26 January 2021, Accepted on: 22 March 2021

\begin{abstract}
A field experiment was carried out at Horticultural Research Station, Rajikot, Jumla to determine the best grafting date of walnut for the highest graft-take success and sapling growth. The experiment was conducted during the two consecutive years 2017, and 2018. Two varieties namely 'Hartley' and 'Payne' and four different dates of grafting viz. $15^{\text {th }}$ March, $22^{\text {nd }}$ March, $29^{\text {th }}$ March, and $5^{\text {th }}$ April were used as the treatment and the experiment was laid out in split-plot design. Each treatment was assigned with ten grafts with five replications per treatment. The measured parameters for the experiments included graft-take success (\%), final scion diameter $(\mathrm{cm})$, growth on scion diameter $(\%)$, number of primary branches per plant, plant spread $(\mathrm{cm})$, and number of leaf per plant. The pooled value of observation for two years showed highly significant effect of variety and grafting date on grafting-take. 'Hartley' variety showed maximum graft-take success $(73.2 \%)$ and 'Payne' with the least success (54.0\%). The pooled value of two successive years showed the highest grafttake success $(70.0 \%)$ on $15^{\text {th }}$ of March, significantly at par with $22^{\text {nd }}$ March $(64.5 \%)$ and $29^{\text {th }}$ March $(67.0 \%)$ grafting. Grafting on $15^{\text {th }}$ March was also superior in terms of number of leaves (31.7), and least was observed for grafting on $29^{\text {th }}$ March (20.5). In essence, variety 'Hartley' was found to record higher graft-take success with $15^{\text {th }}$ March as the optimum grafting date under Jumla condition.
\end{abstract}

Keywords: Juglans regia L., in situ grafting, tongue-grafting, callus, graft-take success

\section{Introduction:}

Walnut (Juglans regia L.) is a famous fruit tree belonging to the family Juglandaceae. It is a native nut fruit of Persia and Northern Western Himalayan (Singh et al., 2019). It is a highly nutritious nut fruit containing a fair amount of proteins, fiber, vitamin-B, minerals and anti-oxidants such as vitamin $\mathrm{E}$ and omega-3 fatty acids. Besides, it is rich in unsaturated fatty acids, including oleic, linoleic, and linolenic acids (Maguire et al.,
2004). It has multipurpose use with kernels consumed as fresh and utilized in confectionary and extracting edible oil. Besides, the trees are valued for its timber as furniture, craving and butt of guns. Walnut is grown in almost all the temperate countries of the world in the semi-cold region. In Nepal, among the fruit grown in the high hills, it is next crucial temperate fruit after apple. It is found in almost all part of high hill districts 
accommodating the height of 2,000-2,500 meter above mean sea level (HRS, 2017). The local type of hard shelled walnut (Hade) is abundantly found in forests of subtropical and temperate region of Nepal. Some of the exotic thin shelled varieties such as 'Hartley', 'Payne' and 'Ashley' are becoming popular in the commercial farm due to their economic value.

The propagation of walnut is done either by seed or vegetative means. Vegetatively, it can be propagated by grafting, budding, stooling, and micro-propagation, while rooting of cuttings and layers has not been successful (Mitra et al., 1991). The existing plantations in Nepal have a seedling origin with extreme variability in production, quality, color, shape, and size of nuts and kernels. The nut trees with seedlings origin have a long juvenile period, low productivity and unmanageable tree size causing a great concern for walnut farmers. Grafting in walnuts is a tedious and challenging job to accomplish than in other pome and stone fruits (Vahdati, 2003; Vahdati, 2006). It requires more precision in grafting operation and handling stock and scion (Mitra et al., 1991). The low graft success rate has been considered one of the significant factors in the mass propagation of superior walnut selections (Ozkan and Gumus, 2001). The lower graft success rate in walnut is due to the lower callus formation rate (Kruniyuki and Ford, 1985). The lower rate is mainly due to the presence of high concentration of phenolic compounds in the tissue and their oxidation by wounding (Rongting and Pinghai, 1993; Coggshall and Beineke, 1997). Other factors such as environmental condition, physiological status of scion wood and grafting time equally contribute to the success rate of grafting (Gandev, 2009).

Among the above constraints, the grafting time is one of the crucial factors under a particular environment condition. An experiment conducted at the outreach site of Horticultural Research Station, Rajikot, Jumla proved the highest graft-take success $(35 \%)$ through tongue grafting followed by cleft grafting $(25 \%)$ and side grafting (15\%) under open field condition (HRS, 2014). Keeping this in mind, an attempt was made to standardize the ideal grafting date in Nepal's hills with specific to commonly adopted thin shelled varieties.

\section{Materials and Methods:}

This experiment was carried out at Horticultural Research Station (HRS), Rajikot, Jumla (latitude of $29.25^{\circ}$ North and longitude of $82.16^{\circ}$ East) for two consecutive years, 2017 and 2018, altitude of 2,390 masl. The experiment was performed with two Persian walnut varieties, viz. 'Hartley' and 'Payne' with four different grafting dates viz. $15^{\text {th }}$ March, 22 ${ }^{\text {nd }}$ March, $29^{\text {th }}$ March, and $5^{\text {th }}$ April. The experiment was laid in two factorial split-plot designs with five replications, and ten grafts were assigned per treatment for data observation and recording. The variety was considered the main plot factor (Factor A), and four grafting dates were considered sub-plot factors (Factor B). The seedlings of one-year-old hard shell walnut were used as rootstock, which was grown in a nursery bed at $40 \times 15 \mathrm{~cm}$ spacing. The scions for the two varieties were collected from the germplasm maintained at HRS, Rajikot, Jumla. The scions were taken just before grafting from the mother plant and kept moist by wrapping them on the wet gunny bags to avoid desiccation. Grafting was performed with tongue method under in situ in the open condition at 10-12 cm height onto the rootstocks. The grafting was carried out in a slightly different manner than the farmer's practice. The entire region from graft union to the tip of scion was covered by paraffin tape to create a air tight condition for preventing the probability of scion's desiccation. After grafting, irrigation was done at seven days intervals. All the intercultural operations like desuckering, weeding, etc., and plant protection measures were carried out as per the need. Seven months after grafting, the observations were recorded on ten selected plants of each replication to identify graft-take success (\%). Five grafts were selected per bed to find the final scion diameter $(\mathrm{cm})$, growth on scion diameter $(\%)$, number of primary branches, plant spread $(\mathrm{cm})$, and number of leaves per plant. The number of successful graft was recorded for each treatment at the end of the growing season.

\section{Initial observation}

Initial height and diameter of the grafts was recorded just after completing the grafting operations. Initial observation of the graft was used in calculating the final growth of the graft in term of height and diameter.

\section{Final observation}

Final observation on graft-take success, plant height, diameter of sapling, number of shoots per plant, plant spreading and number of leaves per plant was done at seven months after grafting (end of growing season of the grafts). 


\section{Graf-take success (\%)}

Graft-take success of individual treatment was calculated by using the following formula:

Number of successful grafts $\times 100$

Total number of grafts

\section{Growth (\%) over initial height}

Growth of sapling height over the initial height was calculated using the following formula:

Final height $(\mathrm{cm})$-Initial height $(\mathrm{cm}) \times 100$ Initial height $(\mathrm{cm})$

\section{Growth (\%) over initial diameter}

Similarly, growth of sapling diameter over initial diameter was calculated using the following formula:

Final diameter $(\mathrm{cm})$-Initial diameter $(\mathrm{cm}) \times 100$ Initial diameter $(\mathrm{cm})$

\section{Number of shoots per plant}

It was recorded by counting the number of primary branches per plant and averaged.

\section{Plant spreading}

Plant spreading was calculated by averaging the spreading of east-west and north-south direction of the sapling.

The data obtained from the experiment were transcribed to MS-Excel (Microsoft Excel.2010). Mean values of the parameters in each replication were statistically analyzed through R Software 3.1.1 (R Core Team, 2014). Statistical testing was carried out using Duncan's New Multiple Range Test at the $\mathrm{P}<0.05$ level. Microsoft Excel was used for plotting figures and graphs.

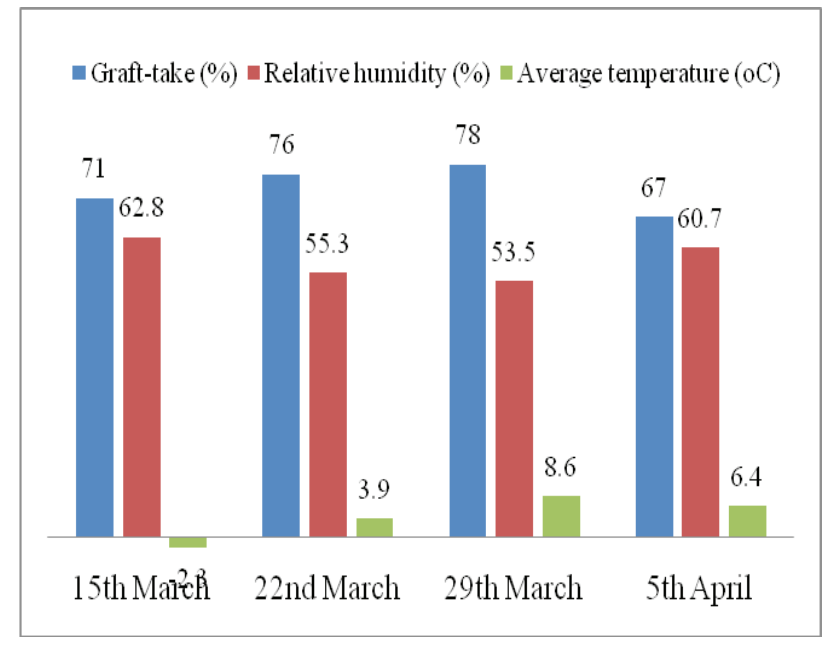

Figure 1. Graft-take (\%), maximum and minimum temperature (oC) pattern in Jumla of Nepal, 2017
-Graft-take (\%) $\square$ Relative humidity (\%) $\backsim$ Average temperature (oC)

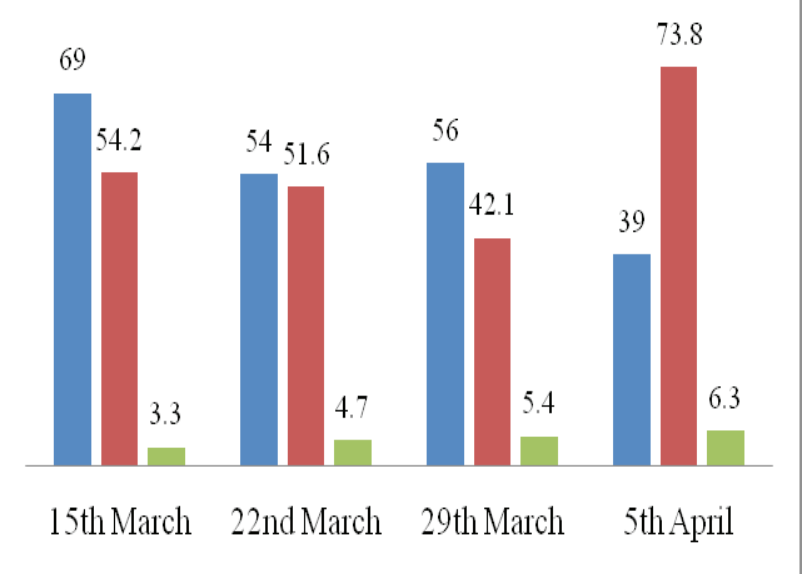

Figure 2. Graft-take (\%), maximum and minimum temperature $\left({ }^{\circ} \mathrm{C}\right)$ pattern in Jumla of Nepal, 2018

\section{Results:}

\section{Graft-take success:}

The effect of variety on the graft-take success was observed significant in 2017 and highly significant in 2018. The pooled values showed that grafting success was highly significant due to variety. The highest success rate $(73.20 \%)$ was observed on the variety 'Hartley' (Table 1).

The effect of date of grafting on graft-take success was found non-significant during 2017 and significant in 2018. The pooled data of the two years showed the considerable impact of grafting date on the graft-take. Considering the pooled data, the highest graft take success was recorded on $15^{\text {th }}$ March grafting (70.00\%) which was statistically at par with grafting on $22^{\text {nd }}$ March (64.50\%) and 29 $9^{\text {th }}$ March (67.00\%) grafting. The lowest success was found on $5^{\text {th }}$ April grafting (53.00\%) (Table 1). 
Table 1. Effect of variety and date of grafting on graft-take success (\%) during 2017 and 2018 at Horticultural Research Station, Rajikot, Jumla, Nepal

\begin{tabular}{|c|c|c|c|}
\hline Treatments & 2017 & 2018 & Pooled \\
\hline \multicolumn{4}{|l|}{ Variety (A) } \\
\hline 'Hartley' & 79.00 & 67.50 & 73.20 \\
\hline 'Payne' & 66.50 & 41.50 & 54.00 \\
\hline $\mathrm{F}$ Test A & $0.032 *$ & $<0.001^{* *}$ & $<0.001 * *$ \\
\hline $\operatorname{SEM}( \pm)$ & 2.74 & 1.32 & 2.15 \\
\hline LSD & 10.75 & 5.19 & 5.97 \\
\hline \multicolumn{4}{|l|}{ Date of grafting (B) } \\
\hline $15^{\text {th }}$ March & 71.00 & $69.00^{\mathrm{a}}$ & $70.00^{\mathrm{a}}$ \\
\hline $22^{\text {nd }}$ March & 76.00 & $54.00^{\mathrm{b}}$ & $64.50^{\mathrm{a}}$ \\
\hline $29^{\text {th }}$ March & 78.00 & $56.00^{\mathrm{ab}}$ & $67.00^{\mathrm{a}}$ \\
\hline $5^{\text {th }}$ April & 67.00 & $39.00^{c}$ & $53.00^{\mathrm{b}}$ \\
\hline F Test B & NS & $0.002 *$ & $0.007 *$ \\
\hline $\operatorname{SEM}( \pm)$ & 3.70 & 4.77 & 4.73 \\
\hline LSD & 10.79 & 13.92 & 9.71 \\
\hline F Test A x B & NS & NS & NS \\
\hline CV $(\%)$ & 16.10 & 27.70 & 29.70 \\
\hline GM & 72.80 & 54.50 & 63.60 \\
\hline $\operatorname{SEM}( \pm)$ & 5.29 & 5.99 & 6.27 \\
\hline
\end{tabular}

Note: NS, * and ** indicate non-significant, significant at $\mathrm{P}<0.05$, and $\mathrm{P}<0.01$, respectively. Means followed by the same letter (s) in the column are not significantly different at $5 \%$ by DMRT.

\section{Plant height:}

Effect of variety and date of grafting on plant height was found significant result. The observed data showed that the plant height growth was significantly the highest in 'Payne' variety as compared to the 'Hartley' at seven months after grafting (Table 2).

During both the years, variety 'Payne' $(102.00 \mathrm{~cm}$ and $96.70 \mathrm{~cm}$ in 2017 and 2018 respectively) recorded the highest plant height then 'Hartley' (84.70 cm and 83.80 $\mathrm{cm})$. The pooled data indicated that variety 'Payne' produced significantly higher plant height $(99.30 \mathrm{~cm})$ than 'Hartley' $(84.30 \mathrm{~cm})$. The growth (\%) shows around $481.90 \%$ and $606.40 \%$ increment of plant height of variety 'Payne' and 'Hartley' respectively over the initial plant height at seven months after grafting (Table 2).

Table 2. Effect of variety and date of grafting on plant height growth during 2017 and 2018 at Horticultural Research Station, Rajikot, Jumla, Nepal

\begin{tabular}{|l|c|c|c|c|c|c|}
\hline \multirow{2}{*}{ Treatments } & \multicolumn{3}{|c|}{$\begin{array}{c}\text { Plant height (cm) at 7 months after } \\
\text { grafting }\end{array}$} & \multicolumn{3}{c|}{$\begin{array}{c}\text { Growth over initial height (\%) at 7 months } \\
\text { after grafting }\end{array}$} \\
\cline { 2 - 7 } & $\mathbf{2 0 1 7}$ & $\mathbf{2 0 1 8}$ & Pooled & $\mathbf{2 0 1 7}$ & $\mathbf{2 0 1 8}$ & Pooled \\
\hline Variety (A) & \multicolumn{7}{|c}{} \\
\hline 'Hartley' & 84.70 & 83.80 & 84.30 & 486.10 & 477.70 & 481.90 \\
\hline 'Payne' & 102.00 & 96.70 & 99.30 & 656.90 & 555.80 & 606.40 \\
\hline F Test A & $0.045^{*}$ & $0.002^{*}$ & $0.003^{*}$ & $0.026^{*}$ & $0.023^{*}$ & $0.001^{*}$ \\
\hline SEM $( \pm)$ & 4.24 & 1.26 & 2.43 & 34.83 & 15.38 & 15.11 \\
\hline
\end{tabular}




\begin{tabular}{|l|c|c|c|c|c|c|}
\hline \multirow{2}{*}{ Treatments } & \multicolumn{3}{|c|}{$\begin{array}{c}\text { Plant height (cm) at 7 months after } \\
\text { grafting }\end{array}$} & \multicolumn{3}{c|}{ Growth over initial height (\%) at 7 months } \\
after grafting
\end{tabular}

Note: NS, * and ** indicate non-significant, significant at $\mathrm{P}<0.05$, and $\mathrm{P}<0.01$, respectively. Means followed by the same letter (s) in the column are not significantly different at $5 \%$ by DMRT.

\section{Sapling diameter:}

Effect of variety on diameter at seven months after grafting was non-significant. However, the sapling diameter growth percentage over the initial diameter was significant in 2017 while it was non-significant during 2018. The pooled data of 2017 and 2018 showed it was again non-significant at seven months after grafting (Table 3).

The effect of grafting date on sapling diameter growth at seven months of grafting showed mixed results. The result of 2017 was significant and the highest scion diameter $(1.20 \mathrm{~cm})$ was recorded on $15^{\text {th }}$ March, $22^{\text {nd }}$ March and $5^{\text {th }}$ April grafting whether the result of 2018 and the pooled data was non-significant. Similarly, the grafting dates' effect on the growth of scion diameter over initial diameter was highly significant in 2017 and non-significant in 2018. The pooled data indicated that the effect was significant, and the highest growth was recorded on the $15^{\text {th }}$ March, $22^{\text {nd }}$ March and $5^{\text {th }}$ April grafting respectively (Table 3 ).

Table 3. Effect of variety and date of grafting on scion diameter growth during 2017 and 2018 at Horticultural Research Station, Rajikot, Jumla, Nepal

\begin{tabular}{|c|c|c|c|c|c|c|}
\hline \multirow[t]{2}{*}{ Treatments } & \multicolumn{3}{|c|}{$\begin{array}{l}\text { Scion diameter (cm) at } 7 \text { months } \\
\text { after grafting }\end{array}$} & \multicolumn{3}{|c|}{$\begin{array}{c}\text { Growth over initial scion diameter (\%) } \\
\text { at } 7 \text { months after grafting }\end{array}$} \\
\hline & 2017 & 2018 & Pooled & 2017 & 2018 & Pooled \\
\hline \multicolumn{7}{|l|}{ Variety (A) } \\
\hline 'Hartley' & 1.10 & 1.10 & 1.10 & 19.50 & 14.90 & 17.20 \\
\hline 'Payne' & 1.20 & 1.10 & 1.10 & 26.20 & 18.10 & 22.10 \\
\hline F Test A & NS & NS & NS & $0.086^{*}$ & NS & NS \\
\hline SEM $( \pm)$ & 0.03 & 0.02 & 0.03 & 2.07 & 1.82 & 2.44 \\
\hline LSD & 0.11 & 0.07 & 0.08 & 8.14 & 7.14 & 6.78 \\
\hline \multicolumn{7}{|c|}{ Dates of grafting (B) } \\
\hline $15^{\text {th }}$ March & $1.20^{\mathrm{a}}$ & 1.10 & $1.20^{\mathrm{a}}$ & $29.10^{\mathrm{a}}$ & 16.50 & 22.80 \\
\hline $22^{\text {nd }}$ March & $1.20^{\mathrm{a}}$ & 1.10 & $1.20^{\mathrm{a}}$ & $28.10^{\mathrm{a}}$ & 17.00 & 22.50 \\
\hline $29^{\text {th }}$ March & $1.10^{\mathrm{b}}$ & 1.10 & $1.10^{\mathrm{b}}$ & $10.10^{\mathrm{b}}$ & 12.20 & 11.20 \\
\hline $5^{\text {th }}$ April & $1.20^{\mathrm{a}}$ & 1.10 & $1.20^{\mathrm{a}}$ & $24.10^{\mathrm{a}}$ & 20.30 & 22.20 \\
\hline F Test B & $0.02 *$ & NS & $0.026^{*}$ & $0.019 * *$ & NS & $0.002 *$ \\
\hline SEM $( \pm)$ & 0.04 & 0.02 & 0.03 & 4.40 & 2.14 & 3.17 \\
\hline
\end{tabular}




\begin{tabular}{|l|c|c|c|c|c|c|}
\hline \multirow{2}{*}{ Treatments } & \multicolumn{3}{|c|}{$\begin{array}{c}\text { Scion diameter (cm) at 7 months } \\
\text { after grafting }\end{array}$} & \multicolumn{3}{c|}{$\begin{array}{c}\text { Growth over initial scion diameter (\%) } \\
\text { at 7 months after grafting }\end{array}$} \\
\cline { 2 - 7 } & $\mathbf{2 0 1 7}$ & $\mathbf{2 0 1 8}$ & Pooled & $\mathbf{2 0 1 7}$ & $\mathbf{2 0 1 8}$ & Pooled \\
\hline LSD & 0.12 & 0.06 & 0.06 & 12.83 & 6.25 & 6.49 \\
\hline F Test A x B & NS & NS & NS & NS & NS & NS \\
\hline CV (\%) & 10.80 & 5.80 & 11.40 & 60.80 & 41.00 & 61.70 \\
\hline GM & 1.20 & 1.10 & 1.10 & 22.80 & 16.50 & 19.70 \\
\hline SEM $( \pm)$ & 0.06 & 0.03 & 0.05 & 5.77 & 3.19 & 4.44 \\
\hline
\end{tabular}

Note: NS, * and $* *$ indicate non-significant, significant at $\mathrm{P}<0.05$, and $\mathrm{P}<0.01$, respectively. Means followed by the same letter (s) in the column are not significantly different at $5 \%$ by DMRT.

\section{Number of shoots and plant spread:}

The effect of variety on the production of shoots was non-significant. The number of branches varied from 1.00 to 1.10 in first year and in the second year it was much similar to first year. Similarly, the effect of grafting dates on the production of shoots was also statistically non-significant in both the years. The pooled data of the two years also recorded non-significant results among the different grafting dates (Table 4).

The effect of variety on plant spread was nonsignificantly varied from $25.30 \mathrm{~cm}$ to $31.30 \mathrm{~cm}$ in 2017 and $24.40 \mathrm{~cm}$ to $34.40 \mathrm{~cm}$ in 2018 . The effect of grafting dates on plant spread was significant in 2017,
2018, and pooled data of the two years. During the first year, the highest spreading $(35.40 \mathrm{~cm})$ was recorded on $22^{\text {nd }}$ March grafting and was statistically at par with $15^{\text {th }}$ March $(29.20 \mathrm{~cm})$ and $5^{\text {th }}$ April $(27.70 \mathrm{~cm})$ grafting. The lowest spreading was observed on $29^{\text {th }}$ March grafting. In 2018, the highest spread was recorded on $15^{\text {th }}$ March grafting which was statistically at par with $22^{\text {nd }}$ March and $5^{\text {th }}$ April. The pooled data of the two years of experiment was significant among the different grafting dates. The highest plant spread was recorded on $22^{\text {nd }}$ March grafting followed by $15^{\text {th }}$ March and $5^{\text {th }}$ April (Table 4).

Table 4. Effect of variety and grafting dates on production of shoots and plant spread during 2017 and 2018 at Horticultural Research Station, Rajikot, Jumla, Nepal

\begin{tabular}{|c|c|c|c|c|c|c|}
\hline \multirow[t]{2}{*}{ Treatments } & \multicolumn{3}{|c|}{$\begin{array}{c}\text { Number of shoots per plant at } 7 \text { months } \\
\text { after grafting }\end{array}$} & \multicolumn{3}{|c|}{$\begin{array}{c}\text { Plant spread (cm) at } 7 \text { months after } \\
\text { grafting }\end{array}$} \\
\hline & 2017 & 2018 & Pooled & 2017 & 2018 & Pooled \\
\hline \multicolumn{7}{|l|}{ Variety (A) } \\
\hline 'Hartley' & 1.00 & 1.00 & 1.00 & 25.30 & 26.40 & 25.90 \\
\hline 'Payne' & 1.10 & 1.00 & 1.10 & 31.30 & 34.40 & 32.90 \\
\hline F Test A & NS & NS & NS & NS & NS & NS \\
\hline SEM $( \pm)$ & 0.03 & 0.02 & 0.03 & 1.82 & 2.86 & 3.07 \\
\hline LSD & 0.13 & 0.09 & 0.07 & 7.16 & 11.23 & 8.53 \\
\hline \multicolumn{7}{|c|}{ Dates of grafting (B) } \\
\hline $15^{\text {th }}$ March & 1.10 & 1.00 & 1.10 & $29.20^{\mathrm{ab}}$ & $34.80^{\mathrm{a}}$ & $32.00^{\mathrm{a}}$ \\
\hline $22^{\text {nd }}$ March & 1.00 & 1.10 & 1.00 & $35.40^{\mathrm{a}}$ & $33.20^{\mathrm{a}}$ & $34.30^{\mathrm{a}}$ \\
\hline $29^{\text {th }}$ March & 1.00 & 1.00 & 1.00 & $21.00^{\mathrm{b}}$ & $23.80^{\mathrm{b}}$ & $22.40^{\mathrm{b}}$ \\
\hline $5^{\text {th }}$ April & 1.00 & 1.10 & 1.00 & $27.70^{\mathrm{ab}}$ & $29.80^{\mathrm{ab}}$ & $28.80^{\mathrm{ab}}$ \\
\hline F Test B & NS & NS & NS & $0.037 *$ & $0.007 *$ & $0.007 *$ \\
\hline $\operatorname{SEM}( \pm)$ & 0.05 & 0.03 & 0.05 & 3.25 & 2.16 & 3.28 \\
\hline LSD & 0.16 & 0.10 & 0.11 & 9.49 & 6.31 & 6.73 \\
\hline $\mathrm{F}$ Test A x B & NS & $\mathrm{NS}$ & NS & NS & NS & NS \\
\hline CV (\%) & 16.20 & 10.10 & 10.50 & 36.30 & 22.50 & 24.30 \\
\hline GM & 1.00 & 1.00 & 1.00 & 28.30 & 30.40 & 29.40 \\
\hline $\operatorname{SEM}( \pm)$ & 0.07 & 0.05 & 0.07 & $\begin{array}{l}4.38 \\
\end{array}$ & 3.90 & 4.97 \\
\hline
\end{tabular}

Note: NS, * and ** indicate non-significant, significant at $\mathrm{P}<0.05$, and $\mathrm{P}<0.01$, respectively. Means followed by the same letter (s) in the column are not significantly different at $5 \%$ by DMRT. 


\section{Leaf number per plant:}

Effect of variety on the production of a leaf was nonsignificantly differed from 26.10 and 27.80 in 'Hartley' and 'Payne' variety respectively during 2017 at seven months after grafting. In the second year, it was also non-significantly varied from 22.70 and 27.60 at seven months of grafting (Table 5).
The pooled data from the two years at seven months after grafting indicated that the effect of date of grafting was significant and highest number of leaf was recorded on $15^{\text {th }}$ March followed by $22^{\text {nd }}$ March and $5^{\text {th }}$ April grafting (Table 5).

Table 5. Effect of variety and grafting date on number of leaf per plant during 2017 and 2018 at Horticultural Research Station, Rajikot, Jumla, Nepal

\begin{tabular}{|c|c|c|c|}
\hline Treatments & 2017 & 2018 & Pooled \\
\hline \multicolumn{4}{|l|}{ Variety (A) } \\
\hline 'Hartley' & 26.10 & 22.70 & 24.40 \\
\hline 'Payne' & 27.80 & 27.60 & 27.70 \\
\hline F Test A & NS & NS & NS \\
\hline $\operatorname{SEM}( \pm)$ & 2.43 & 1.99 & 1.43 \\
\hline LSD & 9.53 & 7.80 & 3.97 \\
\hline \multicolumn{4}{|c|}{ Dates of grafting (B) } \\
\hline $15^{\text {th }}$ March & 30.20 & $33.10^{\mathrm{a}}$ & $31.70^{\mathrm{a}}$ \\
\hline $22^{\text {nd }}$ March & 29.20 & $23.10^{\mathrm{b}}$ & $26.10^{\mathrm{ab}}$ \\
\hline $29^{\text {th }}$ March & 19.20 & $21.70^{\mathrm{b}}$ & $20.40^{\mathrm{b}}$ \\
\hline $5^{\text {th }}$ April & 29.20 & $22.80^{\mathrm{b}}$ & $26.00^{\mathrm{ab}}$ \\
\hline F Test B & NS & $0.003 *$ & $0.006^{*}$ \\
\hline $\operatorname{SEM}( \pm)$ & 2.79 & 2.16 & 2.85 \\
\hline LSD & 8.14 & 6.30 & 5.85 \\
\hline F Test A x B & $0.001 *$ & NS & $0.007 *$ \\
\hline CV (\%) & 32.70 & 27.10 & 41.60 \\
\hline GM & 26.90 & 25.20 & 26.10 \\
\hline SEM $( \pm)$ & 4.19 & 3.31 & 3.23 \\
\hline
\end{tabular}

Note: NS, * and ** indicate non-significant, significant at $\mathrm{P}<0.05$, and $\mathrm{P}<0.01$, respectively. Means followed by the same letter (s) in the column are not significantly different at $5 \%$ by DMRT.

\section{Discussion:}

The grafting was started in March because it was common practice in Jumla (HRS, 2014). At that time the scion and rootstock remain still at dormant stage and temperature starts raising from March. In the Jumla condition of Nepal, the maximum graft success in the 'Hartley' walnut was might be due to the optimum physiological stage than the 'Payne' variety during the selected date of grafting. Earlier sprouting of bud was observed in 'Payne', which could be the reason for lower graft success as compared to 'Hartley'. The highest success rate on the first date ( $15^{\text {th }}$ March) might be due to the favorable temperature and relative humidity following grafting, which allows rapid sap flow in stock and scion and thus complimenting the healing process. The cambium of the graft partners and parenchyma cells comprising the important callus tissue are thin-walled and tender, with provision for resisting desiccation. Unless the adjoining tissues of a completed graft union are kept at a very high humidity level, the chances of successful healing are poor. With most plants, through waxing of the graft union or sealing of the graft union with polyethylene grafting tape or parafilm helps for retaining the natural moisture and aeration adequate moisture (Hartmann et 
al., 2007). If exposed to drying air, they will be killed. Air moisture level below the saturation point inhibited callus formation. The desiccation of cells increases as the moisture level drops so that very little or no callus is formed at all when the water potential falls to a low level (Nanda and Kochhar, 1985).

Water is one of the driving forces for cell enlargement and is necessary for callus bridge formation between the stock and scion. Water must be utilized initially from scion tissue and if below a certain water potential, insufficient water is available for callus formation. Until vascular concentrations are formed, Callus Bridge provides the initial pathway for water, bypassing damaged xylem vessels and tracheids of scion and stock. Within the first three to four days of callus bridge formation, there is recovery of scion water potential; with maturation of the connecting tracheids, water potential and osmotic potential continue to increase; photosynthesis declines and does not increase until xylem connections become reestablishment (Hartmann et al., 2007).

Water potential influences of IAA sucrose and their combinations. Hence, the effect of IAA and sucrose also decreases with low water potential. Some callus is produced even at lower water potentials but not at higher concentration of either IAA or sucrose. The differentiation of callus into xylem and phloem also decreases under reduced water potential. However, at slightly lower water potential of -1 and -2 bars, callus in more suberized and has more xylem tissue and vessels than the control. The presence of a film of water around the callusing surface is, therefore, a prerequisite for graft union formation (Nanda and Kochhar, 1985).

Additionally, the whole scion wrapping by the grafting tape created the airtight condition preventing the moisture loss from the scion which inhibited the scion desiccation. Higher graft-take will be obtained in walnut when the mean temperature August reaches $23.5^{\circ} \mathrm{C}$ and relative moisture about $76 \%$. Moreover, higher mean temperature and relative moisture in August period can be expected to increase the graft-take percentage (Karadeniz, 2005). Outside atmospheric temperature and relative humidity during the entire study period was ranged from $-2.3^{\circ} \mathrm{C}$ to $6.4^{\circ} \mathrm{C}$ and $51.6 \%$ to $73.8 \%$ (Figure 1 and 2). However, the entirely wrapped grafting tape might increase the temperature and humidity of the union creating the optimum condition for callus formation. Further, the highest success rate in $15^{\text {th }}$ March might be due to availability of dormant bud in scion at the time of grafting. Temperature and relative humidity play a crucial role in the success of grafting. The high humidity around $15^{\text {th }}$ March favors the formation of parenchyma cells of callus and resulting high grafting success while dry condition led to poor grafts-take due to the moisture loss. According to Rongting and Pinghai (1993) and Vahdati (2006) from January and February, low temperature in winters is the most critical limiting factor for walnut grafting. In a study of walnut under polyhouse and open condition with time of grafting, only $11.85-15.9 \%$ of success rate was recorded from March to $10^{\text {th }}$ of April grafting time with an outside temperature of $9.87-11.25{ }^{\circ} \mathrm{C}$ and relative humidity of 57.9-66.75\% (Wani et al., 2017). Qian-Chun and Chun (2000) also observed the highest grafting success in walnut when grafting was done at the earliest during the dormant season. Mir and Kumar (2011) also reported the similar findings. They found $20 \%$ success through wedge method on $4^{\text {th }}$ week of February and $16.66 \%$ success on $4^{\text {th }}$ week of February through the tongue grafting method. Upadhyay et al. (2017) recorded $25.88 \%$ and $28.50 \%$ graft success under the open field condition during January and February month of grafting respectively through tongue grafting. The graft take success rate was different in the study years which might be due to differences in environmental condition of the atmosphere. Higher temperature was recorded in the 2018 as compared to 2017 (Figure 1 and 2). Compared to the previous research findings of several researchers, the present finding is higher under the open field condition (Table 1).

The effect of variety and grafting date on plant height growth was found to be inconsistent. As compared to the 'Hartley', the variety 'Payne' showed higher growth on plant height over the initial height. This higher growth may be due to the early sprouting of the scion's dormant bud as compared to the 'Hartley'. In addition to this, it might be due to quick graft union formation and healing process in the grafted plant of the first date accompanied by the higher growth rate in this treatment (Table 2). Similar records were also observed by EI-Deen and EI-Rhman (2011) in Pistachio nut where grafting time significantly affected the mean shoot length i.e., the first date of grafting (January) produced significantly higher shoot length compared to later grafting dates (February and March). 
The pooled data from the two year showing the highest scion diameter in variety 'Payne' and the earlier date of grafting might be due to the quicker and strong union and bud sprouting formation during this period of grafting (Table 3). In 'Payne', early sprouted scion produced leaves earlier compared to the late sprouted 'Hartley' which assimilated more food resulting in higher growth on 'Payne'. Upadhyay et al. (2017) found 0.93 and $0.88 \mathrm{~cm}$ scion diameter in walnut graft grafted in January and February month respectively. Kim et al. (1989) observed maximum scion diameter ranging from 2-2.3 cm when tongue grafting was performed on $5^{\text {th }}$ March over another grafting date. These results were in-consistent with Wani et al. (2017) who observed a significant effect of grafting dates on the scion diameter of walnut. Dar (2003) also mentioned environmental conditions are keys to graft success and other growth parameters.

During grafting time, the scion selected was having at least one or two buds per scion. This bud/s ultimately forms the shoot of the graft. Therefore, the effect of variety and grafting date was non-significant for the number of shoots per plant. The effect of variety and grafting dates on plant spreading was statistically significant and the highest spread is recorded on variety 'Payne' compared to the 'Hartley'. The highest spread is due to the early sprouting of 'Payne' and higher assimilation of food for plant growth in both vertical and horizontal direction. Similarly, the grafting done on $22^{\text {nd }}$ March recorded a higher plant spread (Table 4).

The number of leaves per plant at the end of the growing season was affected by the variety and dates of grafting. Comparing 'Payne' to the 'Hartley', number of leaf was observed higher in 'Payne' at the end of growing season (Table 5). The higher number of leaves might be due to the vigorous plant and better union growth that allowed high food intake on the grafted plant. Further, the greater number of a leaf might be favored by the optimum humidity and temperature during the period of grafting. The present result was also supported by Mir and Kumar (2011) who observed 13.33 to 16.66 leaves under the open field condition where as it was 26.66 to 53.33 under the polyhouse condition in walnut graft grafted through tongue grafting method on $2^{\text {nd }}$ week to $4^{\text {th }}$ week of February. Upadhyay et al. (2017) observed a higher number of leaves than the present finding. He reported 59.54 and 71.70 leaves on graft grafted on January and February month under open field condition. Mehta et al. (2018) also recorded the highest number of leaves on the grafted plant of Pecan in the $1^{\text {st }}$ week of March.

\section{Conclusion:}

The present study pointed that the variety 'Hartley' performed better than 'Payne' in terms of graft-take success. Similarly, the two-year pooled value of grafttake success showed the maximum when grafting was carried on $15^{\text {th }}$ March even in the open field condition. The interactive effect of variety and grafting date did not show significant results for most of the observed parameters.

\section{Acknowledgements:}

We would also like to thank Nepal Agriculture Research Council for providing financial assistance to implement this project.

Declaration of conflict of interest and ethical approval:

We all authors mentioned in the manuscript have agreed for authorship, read and approved the manuscript and given consent for submission and subsequent publication. There is no conflict of interest.

\section{Declaration of conflict of interest and ethical approval:}

The authors declare that they don't have any competing interests on the published materials.

\section{References:}

Coggeshall, M.V. \& Beineke, W.F. (1997). Black walnut vegetative propagation: The challenge continues. In: J.W. Van Sambeek (ed.), Proceedings of the Fifth Black Walnut Symposium. USDA Forest Service General Technical Report NC-191, 7077.

Dar, N.A. (2003). Studies on walnut grafting as affected by rootstocks thickness, nut hardiness and environmental conditions. M.Sc. thesis submitted to the Sher-e Kashmir University of Agricultural Sciences and Technology, Kashmir, $\mathrm{J} \& \mathrm{~K}$ India.

EI-Deen, E.M.A.Z. \& EI-Rhman, I.E.A. (2011). Studies on grafting methods and dates of pistachio tree under supplemental irrigation in North Sinai. 
Res. J. Agric. and Biol. Sci., 7(6), 456-463.

Gandev, S. (2009). Propagation of walnut under controlled temperature by the methods of omega bench grafting, hot callus and epicotyl grafting. Bulg. J. Agric. Sci., 15(9), 105-108.

Hartmann, H.T., Kester, D.F. Davies, Jr, F.T. \& Geneve, R.L. (2007). Plant Propagation Principles and Practices $\left(7^{\text {th }}\right.$ ed.). Prentice Hall Pvt. Ltd., New Delhi, India. 880p.

HRS. (2014). Annual Report, 2013/14. Horticultural Research Station, Rajikot, Jumla, Nepal.

HRS. (2017). Annual Report, 2016/17. Horticultural Research Station, Rajikot, Jumla, Nepal.

Karadeniz, T. (2005). Relationships between graft success and climatic values in walnut (Juglans regia L.). Journal of Central European Agriculture, 6(4),631-634.

Kim,Y.K., Park, S.A., Han, M.S. \& Yang, L.S. (1989). The effect of method and date of grafting on graft union development and scion growth in fuji apple on Malussie boldii seedlings. Korean Society of Horticulture, 7, 108-109.

Kruniyuki, A. \& Ford, H. (1985). Walnut Propagation. In: walnut orchard management, D. Ronaas (ed.), Publication 21410, University of California, USA, 38-46.

Maguire, M.S., O’ Sullivan, S.M., Galvin, K., O’ Connor, T.P. \& O’Brien, N.M. (2004). Fatty acid profile, tocopherol, squalene and phytosterol content of walnuts, almonds, peanuts, hazelnuts and the macadamia nut. Int. J.Food Sci. Nutr., 55 (3), 171-178.

Mehta, G., Kumar, R., Bakshi, P., Wali, P.K., Jasrotia, A., Kumar, R., Bhushan, B. \& Bhat, D.J. (2018). Standardization of method and time of grafting on pecan (Carya illinoensis) under intermediate agro-climatic conditions. Indian J. of Agric. Sci., 88 (7), 1088-91.

Mir, M. \& Kumar, A. (2011). Effect of different methods, time and environmental conditions on grafting in walnut. Int. J. Farm Sci., 1 (2), 17-22.

Mitra, S.K., Bose, T.K. \& Rathore, D.S. (1991). Temperate Fruits. Horticulture and Allied Publishers, Calcutta, India.

Nanda, K.K. \& Kochhar, V.K. (1985). Vegetative Propagation of Plants. Kalyani Publishers, New Delhi, India. 234p.
Ozkan, Y. \& Gumus, A. (2001). Effects of different applications on grafting under controlled conditions of walnut. Acta Hortculturae, 544, 515-520.

Qian-Chun \& Qian, C. (2000). Study on walnut seedling grafting techniques. South China Fruit, $29(6), 45$.

R Core Team 3.1.1. (2014). R: A language and environment for statistical computing. $\mathrm{R}$ Foundation for Statistical Computing, Vienna, Austria. URL http://www.R-project.org/.

Rongting, X. \& Pinghai, D. (1993). A study on the uniting process of walnut grafting and the factors affecting. Acta Horticulturae, 311, 160-172.

Singh, L., Awasthi, M., Negi, P. \& Negi, M. (2019). Studies on success rate of grafting methods on walnut (Juglans regia L.) at different time under polyhouse condition. J. Pharmacogn. Phytochem., 8 (4), 2657-2659.

Upadhyay, K., Negi, M. \& Thakur, N. (2017). Studies on different methods and time of grafting in walnut (Juglans regia L.) under different growing conditions. International Journal of Research in Applied, Natural and Social Sciences, 5 (7), 69-74.

Vahdati, K. (2003). Nursery Management and Grafting of Walnut. Khaniran Publication, Tehran.

Vahdati, K. (2006). Evaluation of side setup and hypocotyle grafting efficiency for walnut propagation in Iran. Acta Horticulturae, 705, 347-351.

Wani, R.A., Baba, J.A., Zaffar, G., Hakeem, S.A., Umar, I., Mir, M.A., Alie, B.A., Seerat-unNissa, Bashir, S., Dar, N.A. \& Zubair, M. (2017). Grafting-take success in walnut (Juglans regia) under different environment conditions. Int. J. Curr. Microbiol. App. Sci., 6 (7), 2195-2201. 